\title{
4. Understanding ICT use in labour administration: taking stock
}

\author{
Anna Milena Galazka
}

\subsection{INTRODUCTION}

Since the 1970s, government agencies worldwide have been under increasing pressure to modernize their services by investing in technological infrastructure and skills relating to the use of new information and communication technology (ICT) (Liu and Yuan, 2015; Roux, 2015; Kennedy, 2016; Šiugždinienè et al., 2019). The result has been the emergence of electronic or 'e'-government, which refers to 'the use of technology to enhance the access to and delivery of government services to benefit citizens, business partners and employees' (Silcock, 2001: 88). As observed by Galazka et al. (2020), although interest in the benefits of ICT in public administration has been growing (see Basu, 2004; Bekkers and Homburg, 2007; Shim and Eom, 2009; Arduini et al., 2010; Cordella and Iannacci, 2010), there has been little research on the use of ICT in labour administration. However, a 2015 technical workshop of the International Labour Organization (ILO) on labour administration reforms and innovations highlighted the importance of ongoing research to close the knowledge gaps, with ICT in labour administration a priority topic (Hastings, 2016).

Since the 2010s, harnessing the benefits of technology to improve the efficiency, effectiveness and outreach of labour administration has occupied an increasingly prominent place on the ILO's agenda. Various experts in the labour administration field have emphasized the potential of new technologies to support the activities of labour inspection bodies, public employment services and labour dispute prevention and resolution agencies. Vega (2013), for example, has linked technological advancements with improved dissemination of guidelines on adhering to national occupational safety and health standards and with more effective regulation of the informal economy through standardized collection and sharing of inspection data. Koeltz (2013) has argued that ICT has facilitated the provision of professional assistance to job seekers in finding work placements. The ILO has also commissioned studies 
focused specifically on ICT in labour administration (Fellows, 2010; Galazka, 2015, 2017). Furthermore, the ILO's Future of Work Centenary Initiative has stressed the role of technology in helping to make labour administration sustainable and effective, despite shrinking resources in some countries (ILO, 2016; Vega, 2017).

This chapter takes stock of the trajectory of the ILO's programmes on ICT in labour administration that aim to support the diffusion of 'the benefits of new technologies based on extraordinarily advanced knowledge and capacities', highlighted in the ILO Director-General's Report to the 104th Session of the International Labour Conference (ILO, 2015). It provides an examination of the uses of ICT in labour administration and addresses three questions: What can ICT do that manual labour administration cannot do; what are the expected gains; and how can gains be measured (i.e. how do we know that the benefits exist)?

The chapter is structured as follows. Section 4.2 opens with a summary of studies on technology use in the broad area of public administration. Section 4.3 assesses the uptake of ICT in the field of labour administration, drawing mainly from relevant ILO official reports and academic studies. Section 4.4 examines examples of ICT use in labour administration in both developed and developing economies. Section 4.5 discusses potential challenges to the implementation and use of ICT in labour administration, using illustrations from different functional areas of labour administration. Recommendations for addressing these challenges are also proposed. The evidence presented in Sections 4.4 and 4.5 originate from two sources: firstly, specialists from ILO regional and field offices, who provided input specifically for this chapter, ${ }^{1}$ and secondly, published and unpublished data from projects undertaken by the author on behalf of the ILO (Galazka, 2015, 2017). Section 4.6 concludes the discussion of achievements and stumbling blocks in the use of ICT in labour administration by outlining some practical policy recommendations and their significance for the United Nation's (UN) Sustainable Development Goal 16.

\subsection{TECHNOLOGY IN PUBLIC ADMINISTRATION: AN OVERVIEW}

The emergence of e-government has been one of the most fundamental developments in public administration in recent decades. According to Brown, although the term 'e-government' entered the common language in the early 2000s, its conceptual foundation 'was provided by the New Public Management [NPM], which emerged in the 1980s' (2005: 245). This new management approach required flexible models of operations and more 'managerial' responses from government officials (Blyton and Jenkins, 2007). To this end, ICT offered innovative channels for public sector service delivery 
and internal management modelled on the private sector (see also Charih and Robert, 2004; Brown, 2005; Jho, 2005; Roux, 2015). Further developments that fuelled technological change in the public sector included the reform agendas of the 1990s that encouraged government institutions to build an online presence through websites and the rise of social media at the turn of the twenty-first century that facilitated a move towards electronic democracy (Nasi and Frosini, 2010; Liu and Yuan, 2015). Today, ICT plays a meaningful function that extends, rather than replaces, the governments and governance models familiar to citizens (Nam, 2012: 364). However, ICT in the public sector is still a relatively new and under-researched phenomenon (Liu and Yuan, 2015; Lember et al., 2018: 214).

One useful study for understanding the trajectory of the development of ICT use in public administration is Liu and Yuan's (2015) review of e-government literature from different parts of the world published since the early 1980s. The study sheds light on the key themes explored in e-government research, the types of ICT deployed in public sector organizations and how these tools shape, and are in turn shaped by, changing governance models. Liu and Yuan (2015) observed that early studies of e-government were interested in the use of new technologies for documenting, cataloguing and archiving growing volumes of data (Kim et al., 1987). More recently, an increasing number of studies have examined the interaction between technological tools, e-democracy and citizen participation in policymaking and decision-making on the other (for example, Picazo-Vela et al., 2012; Edgerly et al., 2013). Other topics, such as the deployment of ICT for knowledge sharing and inter-governmental communication remain high on the agenda of e-government debates. New topics are also emerging, such as how public organizations can employ ICT to meet the UN Sustainable Development Goals (SDGs) (see, for example, Corbett and Mellouli, 2017; Wu et al., 2018).

From the early 2000s onwards, the e-government literature has highlighted the potential benefits that ICT offers to internal operations and external service delivery in public administration. Internally, ICT can foster wider horizontal communication and collaboration between civil servants (West, 2004), facilitate greater productivity (Gichoya, 2005), minimize mistakes through manual data entry and calculation and reduce costs through less expensive processing of documents (Ndou, 2004). Integrating new technologies into labour administration activities can also reduce the costs of information dissemination through its capacity for information diffusion (Pina et al., 2010). Externally, ICT can improve citizens' access to the government and increase citizen participation in shaping the direction of policy debates through the provision of more convenient online services to remote users on a 24/7 basis (Toregas, 2001; Welch et al., 2005). Additionally, the use of social media by governments may result 
in greater transparency of government activities, as well as easier transfer of best practices among government agencies (Picazo-Vela et al., 2012).

\subsection{TECHNOLOGY IN LABOUR ADMINISTRATION}

Studies of ICT in labour administration are scarce and often limited to studies of single institutions. Notable examples are Margetts and Willcocks's (1992) analysis of the use of information technology in the UK's Department of Health and Social Security; ${ }^{2}$ Monavvarian and Kasaei's (2007) study of the acquisition, creation, sharing, storage and transfer of knowledge in the Ministry of Labour in Iran; Roux's (2015) case study of the Family Allowance Funds within the French social security system; and Irene and Bunyasi's (2017) report on information systems of the Ministry of Labour Social and Security Services in Kenya. Beyond these examples, however, focused and evidence-driven research into electronic labour administration largely remains an 'uncharted territory'.

In 2010 the use of new technologies in labour administration worldwide was placed on the ILO's study agenda (Fellows, 2010). A key study followed in 2015, with the ILO's first, large-scale initiative to examine the use of new technologies in labour administrations, covering both developed and developing countries (Galazka, 2015). Based on survey responses of 101 labour administration institutions from 81 countries, the study provided comparative statistical information about global trends in the use of ICT in labour administration, outlined the associated benefits and challenges in technology adoption and described various uses of ICT in labour inspection, public employment services and labour dispute prevention and resolution agencies. The study highlighted a rise in the overall level of ICT use globally, with 69 per cent of responding institutions reporting a significant increase, and 27 per cent reporting some increase, in the availability of technological infrastructure and technological capacity of labour agencies. The vast majority (92 per cent) of survey participants recognized the operational benefits of ICT for supporting labour administration practitioners in the execution of their work. However, the overall extent of technological change was notably higher in developed countries than in developing economies. At one extreme, in Lao PDR the Ministry of Labour reported a lack of institutional Intranet or databases for information storing and processing, with employees having to use their own laptops and mobile phones at work. At the other extreme, Estonia has long stood out on the global e-government platform as one of the leaders in introducing new technological solutions into its public sector (Lember et al., 2018). The Estonian Ministry of Labour reported offering a portal where individuals could submit reports on work accidents and occupational diseases to the labour inspectorate while applications to the labour disputes committee could be filed 
electronically by signing the application digitally and sending it via email (Galazka, 2015).

Further analysis of the 2015 survey data (Galazka et al., 2020) focused on the computerization of the three focal functions of labour administration to construct a comparative scale to measure use of new technologies in labour administration in different countries. On this basis, the researchers constructed index values of 'ICT-ness' in labour administration ranging from ' 0 ' (no computerization) to ' 1 ' (complete computerization) (Figure 4.1).

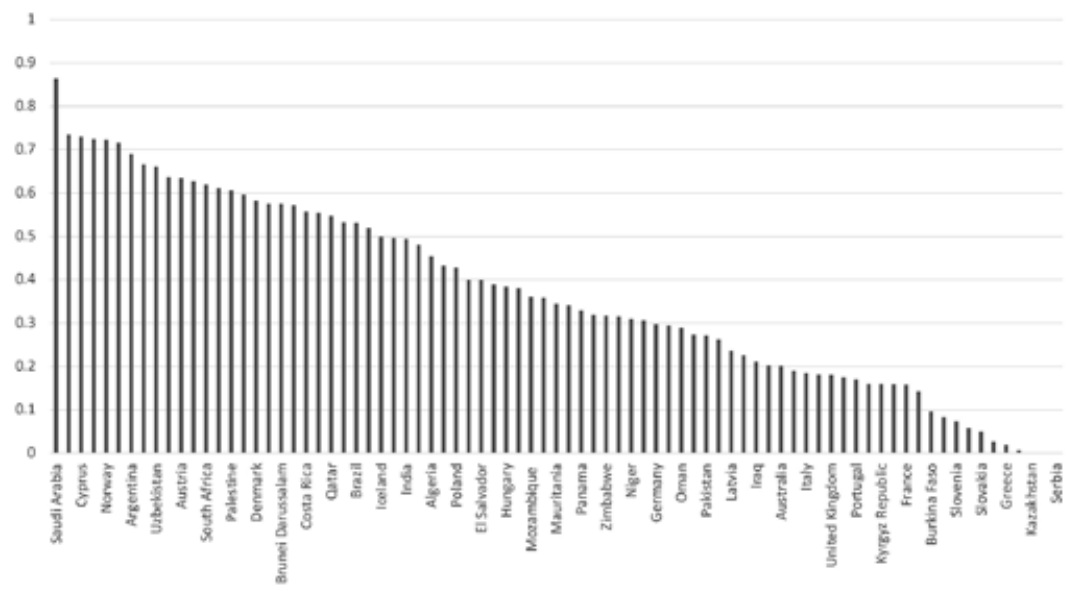

Source: Adapted from Galazka et al. (2020, p. 250).

Figure 4.1 Index of ICT use in labour administration with sample countries

Figure 4.1 compares the scores for the level for ICT-ness for 81 systems of labour administration that participated in the 2015 ILO survey (Galazka, 2015). It shows that there was a high level of variation in the extent of ICT use in labour administration across the countries. Saudi Arabia appeared to lead the way in the extent to which technology was integrated into labour inspection, public employment services and labour dispute prevention and resolution functions. In other parts of the world, however, the extent of computerization was visibly smaller. 


\subsection{BENEFITS OF ICT UPTAKE IN LABOUR ADMINISTRATION}

The scale of ICT adoption and its associated benefits for government operations and communication with the citizens varies from country to country and also across the functions of labour administration. With regard to general trends, the ILO report on global survey into ICT use (Galazka, 2015) showed that 65 per cent of respondents reported improvements in the horizontal communication within public organizations between labour administration practitioners, while 72 per cent believed ICT had led to improved vertical communication between officials at various levels of the organizational hierarchy. The productivity of labour administration practitioners was said to have increased, too, for at least half of the respondents. Transparency and accountability were improved for just over 60 per cent of respondents. Not without significance in this regard was the use of email communication between labour administration institutions and the public. For example, the ILO report (Galazka, 2015) found that the Ministry of Labour of the United Arab Emirates encouraged the use of email communication for all work-related transactions, for it created evidence for the resolution of any labour disputes. The following sections provide further examples of the various uses of ICT within specific functions of labour administration and the associated benefits, covering both developed and developing economies in different ILO regions.

\subsubsection{Labour Inspection}

Labour inspection is the most computerized function of the three functions of public administration considered in the study (Galazka, 2015). Statistically, 56 per cent of labour inspection institutions that responded to the survey had computerized at least one of their functions through adopting various kinds of computerized inspection management systems. In particular, ICT was reported to assist labour administrators with recording complaints about labour law violations (46 per cent of respondents), recording inspection procedures (45 per cent of respondents), registering inspection visits (44 per cent of respondents), creating online profiles of establishments to be inspected (44 per cent of respondents) and producing various statistical reports (43 per cent of respondents). In general, the integration of technology into labour inspection processes helps inspectorates to create detailed records of their inspection processes.

There are a number of interesting examples of ICT use in labour inspection in different countries. The United Arab Emirates (UAE), for example, has extensively automated its labour inspection function and has created an electronic wage protection system, ${ }^{3}$ which has supported the timely payment 
of workers' wages, helped safeguard employees' interests, improved relationships between employers and employees, boosted transparency on wage and salary data and helped reduce labour disputes related to wages and salaries (Sree Consultants, 2019). The UAE has also developed a Smart Inspection System for the prioritization of inspections based on categories of risk and a Labour Market Monitoring System to monitor working conditions, with self-inspection systems and checklists for employers and mobile electronic trackers for labour inspectors on site. These systems have enabled easier remote management of inspection data.

The Colombian Ministry of Labour has developed an Electronic Case Management System (ECMS), which has enabled the Colombian labour inspectorate to increase the number of inspections, generate reports and define new policies to guide inspectors. The most significant gain has been the harmonization of inspectors' criteria with users' guided templates and procedure structures and the introduction of the workflow component. Colombia has also created a virtual campus for the training of labour inspectors at the national level. The first phase of the initiative involved the roll-out of basic training modules focused on administrative procedures, protocols of inspections in critical sectors, criteria to determine the amounts of fines for non-compliance with labour law and checklists for the identification of conduct against the freedom of association. The second phase involved the creation of specialized courses on occupational safety and health and labour migration.

Bangladesh launched a new mobile application for labour inspection in 2018. The initiative involved the distribution of around 250 tablets to the Department of Inspection for Factories and Establishments (DIFE) to help inspectors gather and manage data efficiently and effectively with use of a single electronic platform to replace paper-based inspection. The Labour Inspection Management Application (LIMA) has allowed for improved inspection planning and more efficient data collection and information reporting directly into the LIMA database. It has also enabled employers to quickly report workplace accidents and violations and to make complaints to DIFE about workplace issues, using either the LIMA website or a downloadable smartphone application (Aowsaf, 2018; ILO, 2018a, 2018b).

The Philippines has created a Labour Laws Compliance System Management Information System (LLCS MIS), a computerized system that provides, among other things: automatic monitoring and reporting of establishments assigned for inspection; automatic summary report of the Notice of Results that includes all findings of non-compliance during the course of inspection; a means of integrating the regional database of contractors and subcontractors into the MIS and tagging their enterprise profile with their principal's profile; a case management system; and an online complaints/services system. The Philippines' MIS has enhanced labour inspection via inspection workflows, 
calculators for back wages and sanctions, as well as protocols and procedures such as accident investigation and reporting, case building of labour law violations, coordination of target inter-agency inspections and compliance campaigns (ILO, 2017).

ICT can also be used to address disguised employment relationships. A study by Heyes and Hastings (2017) examined how labour law, taxation and social security enforcement bodies in EU Member States were developing ways of tapping into the potential of ICT to uncover such relationships. An example of reactive enforcement activities involving ICT is the introduction in 2017 of an online tool called Check Employment Status for Tax (CEST) on the UK government's website, which enabled individuals and businesses to check a worker's employment status through asking a series of questions. A further example is the launch in 2013 of an electronic mailbox called MBOX of the Struggle Against Labour Fraud in Spain, which enables individuals to report labour law violations to the Labour and Social Security. As for more proactive activities, European partners are exploring the potential of effectively conducted data mining, which refers to analysing existing datasets in a preventative search for algorithms that help detect unusual behaviours of individual employers and predicting the possibility of fraud (De Wispelaere et al., 2017).

\subsubsection{Public Employment Services}

As for public employment services, the 2015 ILO report (Galazka, 2015) showed that new technologies were often deployed to improve the labour market information available to job seekers. Just under half of all responding institutions reported making use of Internet devices for job seekers' registration, vacancy broadcasting and job matching. For example, the 2015 study found that in the Czech Republic, the Ministry of Labour and Social Affairs cooperated with the Labour Office to facilitate job seekers' access to information on vacancies using an Integrated Portal and without having to register in-person with the Labour Office. Moreover, the dissemination of relevant information and training materials to labour market participants was said to become wider. Specifically, 25 per cent of responding institutions reported using websites to provide information on remuneration, occupational safety and health, employment contracts. Websites were also used for the provision of further information for disadvantaged participants of various workforce segments, like young adults ( 30 per cent of responding institutions), pregnant women and new mothers ( 24 per cent of responding institutions) or workers with disabilities (21 per cent of responding institutions).

Computerization of public employment services can take different forms in different countries. An ambitious example comes from the UK. Motivated by the growing numbers of people who are online and by the desire to find ways 
of reducing costs of helping people find their way out of unemployment, the Department for Work and Pensions (DWP) sought to develop high quality services which are 'digital by default'. As stated in the DWP Digital Strategy:

Well-designed digital services are more efficient for users than their non-digital equivalents . . . Our working-age users in particular need to be confident online to compete in the modern labour market. Many jobs are now only advertised online and most vacancies require digital skills, putting those who are digitally excluded at a disadvantage.

Through collaboration with the Government Digital Service, services such as the Universal Credit, Personal Independence Payment and Carer's Allowance became digital in 2013. Further services available online include My Benefits Online and Universal Jobmatch. The former helps claimants to check details about claims, awards and payments for Job Seeker's Allowance, Employment and Support Allowance, Income Support, Disability Living Allowance and Attendance Allowance. Universal Jobmatch is job search service for job seekers and employers. Recognizing that not all DWP users were online, some Jobcentres run educational sessions to assist claimants in being able to use digital services (DWP, 2012: 12; see also Hastings and Heyes, 2016).

In Denmark, the Danish Agency for Labour Market and Recruitment (STAR) developed a strategy focused on increasing use of self-service facilities among users. Employers can apply online for adult apprentices under a fast, paper-less dialogue-based system. Job seekers can go online to book meetings with their local 'jobcentre.' In the years to come, STAR will move towards 'the virtual jobcentre' - a new concept that aims to personalize and merge the many different offers targeted at job seekers and unemployed (Galazka, 2017, unpublished data).

\subsubsection{Labour Dispute Prevention and Resolution}

Finally, Galazka (2015) revealed that the labour dispute prevention and resolution function was the least computerized labour administration function. Only 26 per cent of respondents reported using a specialized computer-based toolkit for managing workplace conflicts, some of which demonstrated only partial functionalities. A slightly higher percentage (35 per cent) of respondents reported performing at least some workplace conflict prevention and dispute management activities electronically. For example, the Ministry of Labour and Social Security of Jamaica reported using technological tools for the analysis of information, but not for the gathering of data. Similarly, in New Zealand, the Ministry of Business, Innovation and Employment reported creating electronic registers of basic information only, such as the location of mediations. 
Various other services related to labour dispute prevention and resolution all over the world are mediated electronically. In November 2019, the Labour Department of the Government of Hong Kong Special Administrative Region, China, in Asia and the Pacific made available on its website information related to labour disputes handled by the labour relations division, including charts on the numbers and causes of disputes and on the numbers of strikes and days lost due to strikes. ${ }^{4} \mathrm{~A}$ further good example from the region is provided by Australia. The Fair Work Commission, which acts as the national workplace relations tribunal, offers online facilities such as: the Online Learning Centre that facilitates difficult conversations between employees and employers; PayCheck Plus, which is an online tool for calculating award pay rates for both parties; and electronic 'best practice guides' on 13 different topics, including effective work and family, gender pay equity and effective dispute resolution (see Ebisu et al., 2016: 39). In the UK, the mediation body ACAS launched a Helpline Online service in 2013 to offer confidential advice and information on employment rights, rules and dispute resolution options using a chat line as a well as a telephone service (Hastings and Heyes, 2016).

Table 4.1 summarizes the uses of ICT in labour administration and their associated benefits that can be of interest to labour administration decision-makers.

\subsection{CHALLENGES IN IMPLEMENTATION AND USE OF ICT IN LABOUR ADMINISTRATION}

The ability of governments to take full advantage of ICT hinges on their capacity to recognize and tackle the challenges that come with technological transformations. In 2017, the ILO published a report which focused specifically on understanding the general challenges to ICT implementation in labour administration (Galazka, 2017). The study explored four general challenges: lack of sufficient ICT skills amongst the officials and outdated infrastructure; transfer of information on a multi- and cross-institutional basis; issues of transparency of decision-making and accountability; and managing external technology acquisitions. The study was based on qualitative interviews with 24 representatives of national labour administration systems who had participated in the ILO 2015 survey. In the following sections, these challenges are considered in greater detail.

\subsubsection{Insufficient ICT Skills and Outdated Infrastructure}

A stumbling block most often cited by participating labour administration institutions concerned shortages of ICT skills among employees and system obsolescence, sometimes exacerbated by the limited availability of funds to upskill staff and upgrade the infrastructure. 


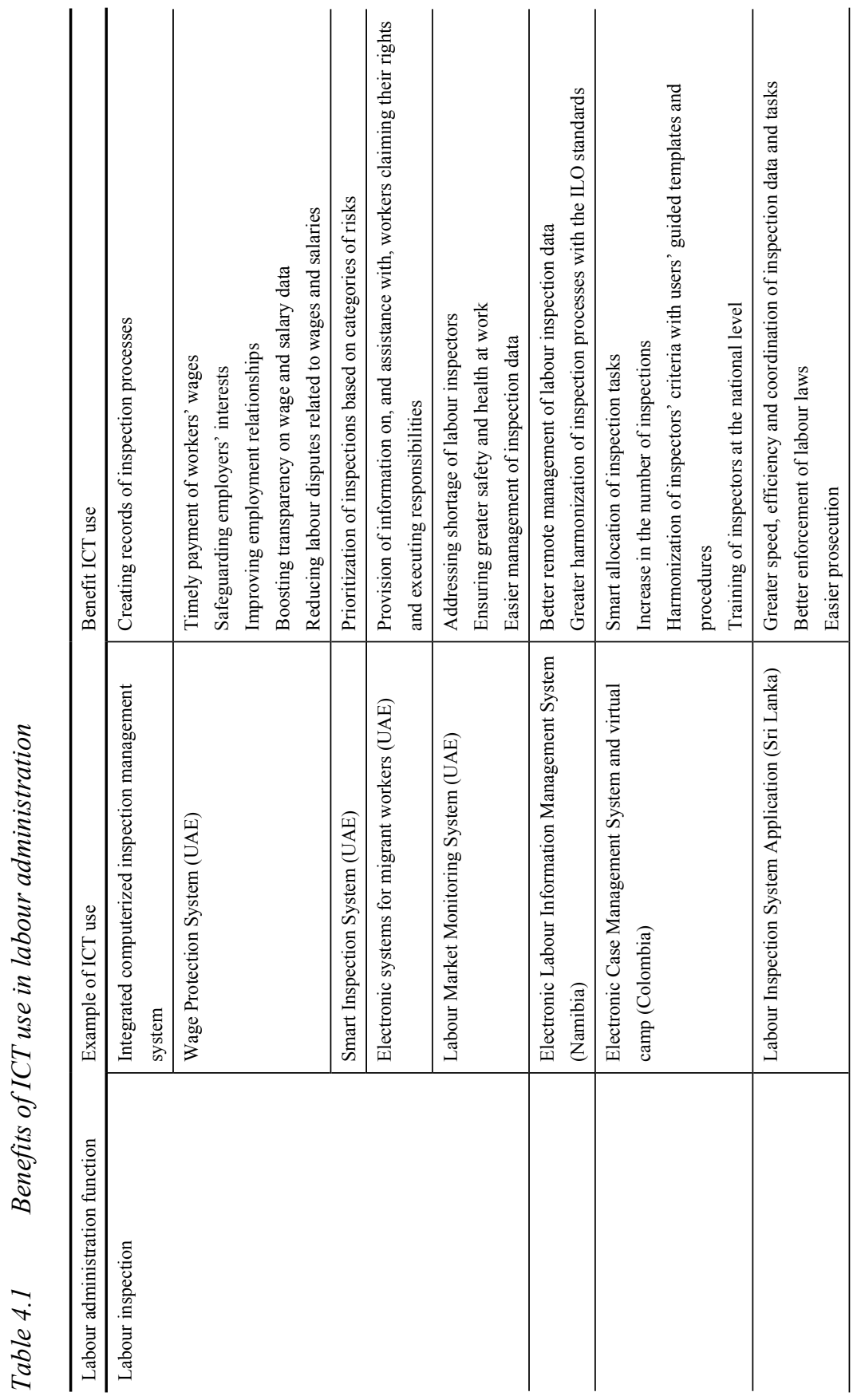




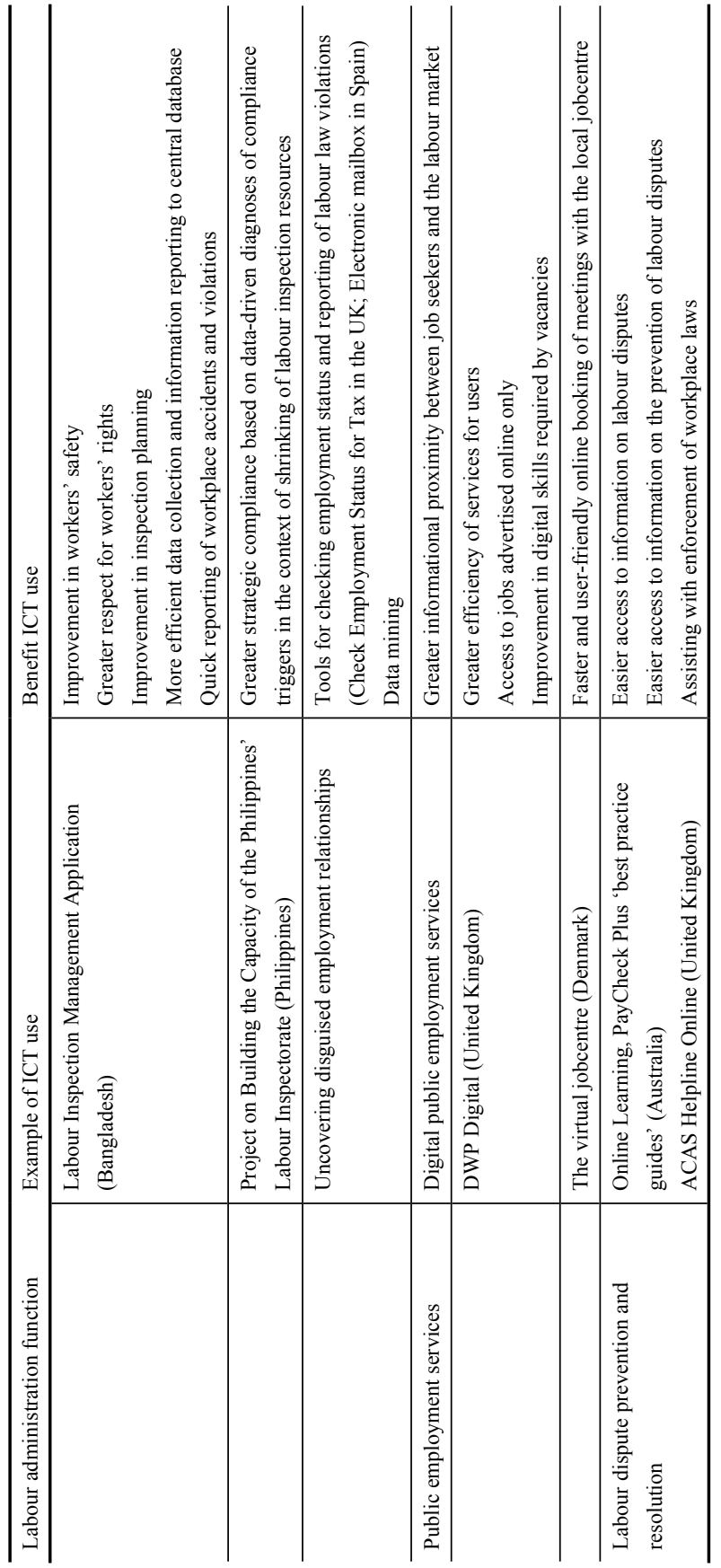


There is clearly a need for training in the use of ICT and advanced logistical support for harnessing its possibilities across functional areas of labour administration. Heron and Van Noord (2004) emphasized the inadequate ICT skills of conciliators in Cambodia while Wark and Thakur (2016) commented on the inadequate technological capacities of labour inspectors. Heyes and Hastings (2017) and Páramo and Vega (2017) have noted the need for innovative proactive technology for spotting non-standard, hard-to-inspect and 'bogus', or 'fake', forms of (self-) employment linked with the rise of the gig economy that makes the use of online platforms such as Uber, Deliveroo or Airbnb.

Galazka (2017) found several examples of insufficient training or problems relating to staff engagement with technology and negative impacts on their lives at work. The development of an engaged and technologically skilled workforce had been written into the ICT strategies of the Ministry of Family, Labour and Social Policy of Poland and the Ministry of Labour or the Ministry of Labour, Family, Social Protection and the Elderly in Romania. However, in Poland, the intimidating scope of new learning required for labour administration practitioners was highlighted while Romania's efforts to improve cybersecurity through investment in new technologies had been hampered by insufficient funding to train staff. A further issue was raised by the Federal Ministry of Labour Social Affairs and Consumer Protection in Austria, which claimed that the introduction of ICT had led to an intensification of the work of civil servants. In other cases, such as the State Labour Inspectorate (SLI) of Latvia, employees were reported to be working with outdated computers and were therefore unable to meet the growing performance requirements.

\subsubsection{Transfer of Information on a Multi- and Cross-institutional Basis}

Galazka (2017) found that some countries experienced problems related to the diversity and disconnectedness of ICT frameworks. For example, the Ministry of Labour, Family, Social Protection and Elderly in Romania noted that a particular challenge in its technological transformation was to provide tools for achieving interoperability between subordinate units and the Ministry in order to facilitate the exchange of information in real time. The Health and Safety Authority in Ireland experienced occasional system crashes, while in Lithuania backlogs of outdated information were linked to inefficiencies in the location of relevant information. By contrast, an example of successful cross-institutional communication came from Denmark, where encrypted messages were sent to institutions that also possessed decryption software through secure Digital Post to prevent data loss and access of unauthorized parties. 


\subsubsection{Issues of Transparency of Decision-making and Accountability}

Galazka's (2017) study also revealed complexities around deploying various ICT tools to boost institutional transparency of decision-making. The tool most often deployed in labour administration to increase transparency was the official institutional website. Social media were also increasingly being used for this purpose, mainly because their usage was easier to monitor. Nonetheless, large volumes of information exchange were said to pose challenges for the ways in which people used electronic information. Requests for information from labour administration institutions must be processed with due consideration of the issues of confidentiality and security. Two ways of coping with this challenge came from Estonia and Lithuania. In Estonia, mobile electronic identification of individuals requesting information was performed through electronic ID cards. In Lithuania, the State Labour Inspectorate was placing open datasets using open formats (CSV, XML, XLS, etc.) on institutional websites to facilitate free and easy access to non-personal and non-critical data to the public. A further example was the Ministry of Labour, Family, Social Protection and Elderly in Romania, which was seeking to increase transparency, accountability and interaction with citizens by publishing on its website (www.mmuncii.gov.ro) information about ongoing and future projects and open datasets (XML file format) on pensions and other social security rights, working conditions, protection of child rights, protection of persons with disabilities, employment, unemployment, social protection and reintegration of unemployed, social services and social assistance and classification of occupations in Romania (Galazka, 2017, unpublished data).

\subsubsection{Managing External Technology Acquisitions}

Finally, the study participants' answers suggested another challenge concerning decisions related to acquiring technological support from outside of the organization versus developing the expertise internally. The Authority for Working Conditions in Portugal believed that the absence of internal skills had led to an excessive dependence on service providers. Therefore, the agency was working hard to strengthen internal competencies and reduce its dependency on external providers.

Although the outsourcing of ICT in the public sector may have helped overcome the shortages of ICT skills in-house, it came with a loss of independence and autonomy and higher costs. For example, deciding on the number of suppliers required careful consideration. On the one hand, collaborating with multiple providers helped prevent dangerous overreliance on one provider only, as explained by the Belgian Federal Public Service Employment, Labour and Social Dialogue. On the other hand, collaborating with a single provider 
Table 4.2 Challenges to ICT use in labour administration and recommendations for policy makers

\begin{tabular}{|c|c|c|}
\hline Dimension of challenge & Specific challenge & Recommendation \\
\hline Staffing and ICT skills & $\begin{array}{l}\text { Insufficient ICT training } \\
\text { Low uptake of email, file sharing } \\
\text { options and social tool solutions } \\
\text { Work intensification } \\
\text { Human weaknesses (inappropriate } \\
\text { use of technology at work) } \\
\text { Cybersecurity threats }\end{array}$ & $\begin{array}{l}\text { Need for more ICT training (including } \\
\text { ICT security training) }\end{array}$ \\
\hline $\begin{array}{l}\text { Transfer of information } \\
\text { on a multi- and } \\
\text { cross-institutional basis }\end{array}$ & $\begin{array}{l}\text { Insufficient ICT tool } \\
\text { interoperability } \\
\text { ICT tool obsolescence } \\
\text { Backlog of outdated information } \\
\text { Unsuitability to user needs } \\
\text { Risks of data loss }\end{array}$ & $\begin{array}{l}\text { Dialogue about computing } \\
\text { environments of other institutions } \\
\text { Design of permission systems to } \\
\text { mitigate risks to data security }\end{array}$ \\
\hline $\begin{array}{l}\text { Issues of transparency of } \\
\text { decision-making }\end{array}$ & $\begin{array}{l}\text { Determining effectiveness of } \\
\text { websites as a tool for greater } \\
\text { transparency } \\
\text { High numbers of information } \\
\text { requests and volume of information } \\
\text { processed } \\
\text { Urgency of verifying the identity } \\
\text { of information seekers to ensure } \\
\text { data security }\end{array}$ & $\begin{array}{l}\text { Tracking website visits and greater } \\
\text { use of social media } \\
\text { Greater availability of open data }\end{array}$ \\
\hline $\begin{array}{l}\text { Managing external } \\
\text { technology acquisition }\end{array}$ & $\begin{array}{l}\text { Risk of overreliance on a single } \\
\text { supplier for ICT knowledge } \\
\text { Risk of poor communication in } \\
\text { case of use of multiple suppliers }\end{array}$ & $\begin{array}{l}\text { Need for transparent multipartite } \\
\text { consultation through careful project } \\
\text { management }\end{array}$ \\
\hline
\end{tabular}

Source: Summary adapted from Galazka (2017: 2-4).

could help pre-empt problems with communication but risked deskilling in-house staff. With multiple stakeholders in place, the report identified the need for consultations through careful project management with multipartite governance structures.

Table 4.2 summarizes the challenges to ICT use in labour administration and broad recommendations for addressing these challenges.

\subsection{CONCLUSION AND RECOMMENDATIONS}

The chapter has shown how the integration of new technologies into labour administration can reinvent the ways in which its agencies perform their 
activities. It concludes by reflecting on the key benefits and main challenges and also by offering a number of recommendations for successful continued technological transformation of labour administration.

\subsubsection{Achievements and Benefits}

The above review evidences the benefits from actual implementations of ICT to the functioning of labour administration agencies. With technological progress, the availability of large databases in the fields of tax, social security, occupational safety and health, labour disputes, job matching or labour inspection, along with a range of automated techniques to extract and analytically relate the data, allow for assessing the risk of non-compliance of entities and accordingly selecting audits using a risk-based approach. New technologies can improve the accuracy of inspection data and enable more effective recording and processing of large volumes of data, thereby enabling the allocation and planning of inspection tasks and facilitating the harmonization of the processes with ILO standards. Technology can to an extent compensate for the shrinking numbers of inspectors and improve access to training for those officers who remain in post. New technologies also have the potential to make job advertising, search and matching easier. Finally, they can improve the transparency of payment processes, improving the timeliness of wage payments and providing easy access to an array of information on workers' rights and workplace laws to reduce disputes that could threaten the employment relationship.

\subsubsection{Challenges and Stumbling Blocks}

With the advancements in technology use in labour administration come related challenges. New forms of online platform-based work, greater need from the public for access to transparent information and increased global collaboration with other institutions and the private sector require technological solutions that keep up with the pace of the changing environment and civil servants who have the desire and courage to learn and are supported in their learning by their employer. Further challenges relate to addressing the need for

efficient and effective interoperability across administrative units and ensuring a safe transfer and sharing of information with other organizations and the public. Deciding to develop technological tools online will have important implications for staff skills, while contracting with external suppliers can pose challenges for communication and open organizations to greater scrutiny from taxpayers. Finally, knowing when to upgrade the systems to maintain a strong infrastructure of cybersecurity is another big challenge. 


\subsubsection{Directions for Future Studies}

The ILO continues to receive requests from governments around the world for assistance with technology implementation. Many requests come from national labour inspection bodies interested in developing technological tools that can facilitate the generation and submission of reports on national compliance with ILO conventions (Hanson, 2018). Moreover, these requests come at a time when the resources available to labour inspections worldwide are shrinking in terms of both falling numbers of labour inspectors and a proportionate increase in the number of establishments to be inspected (see ILO, 2018c).

Future work is required to examine the extent to which there is coordination in data sharing across labour inspection bodies, labour dispute prevention and resolution and public employment services agencies and the reasons why data exchanges may be hampered. Areas of research could include technical obstacles related to the interoperability of data mining across agencies, legal hurdles around privacy or cultural difficulties concerning lack of trust or willingness to exchange decentralized data across authorities (De Wispelaere et al., 2017). Future research could also study and develop protocols for the management of electronic data for straightforward retrieval or trouble-free interpretation of information shared between free open-source packages on the one hand and tailor-made commercial packages on the other (see Stefanov, 2018). The benefits and stumbling blocks in the implementation of innovative ICT tools, such as predictive analytics or geo-fencing with use of electronic GPS maps should also be considered; these tools have already been experimented with in the Australian labour inspection system (Hanson, 2018). Overall, a better understanding of these issues might help labour administration bodies to better implement the new predictive, proactive and targeted strategic models of operations.

\subsubsection{Policy Recommendations}

It is difficult to prescribe detailed next steps to harness the potential of ICT to increase the efficiency, effectiveness and reach of labour administration institutions given the pace of technical change and the differences in the extent of the availability and advancement of technology around the world. However, useful guidance comes from the UN's 11 principles of effective governance for sustainable development, which were agreed at the 17 th session of the Committee of Experts on Public Administration in 2018 and grouped into three categories that build on the essential elements of Sustainable Development Goal 16. The following table synthesizes the chapter's discussion of actual achievements and stumbling blocks in the implementation of ICT in labour 
administration into policy recommendations focused on a number of practical strategies to support the application of the UN principles.

\section{Table 4.3 The role of ICT in practical operationalization and implementation of the principles of effective governance for sustainable development in the global Sustainable Development Goal indicator framework}

\begin{tabular}{l|l}
\hline Principle & Strategy \\
\hline Competence, sound policymaking & - Creation of detailed factual electronic records of inspection and \\
and cooperation under the rubric of & resolution processes \\
effectiveness & - Smart allocation of labour administration tasks \\
& - Implementation of systems and training of labour administration \\
& practitioners in the use of systems (basic training modules and \\
& specialized courses) \\
& - Monitoring working conditions \\
& - Electronic self-inspection reporting \\
\hline Integrity, transparency and & - Use of email communication for all work-related transactions to \\
independent oversight under & evidence for the resolution of any labour disputes \\
accountability & Electronic registration of the payment of wages \\
\hline Leaving no one behind, & - Use of horizontal and vertical electronic communication among \\
non-discrimination, participation, & labour administration practitioners \\
subsidiarity and intergenerational & Electronic registers for migrant workers \\
equity under inclusiveness. & - Electronic facilitation of job seekers' access to information on \\
& vacancies \\
\hline & Electronic dissemination of information and training materials \\
& to labour market participants \\
& Provision of confidential advice, workplace laws and consulta- \\
& tion online \\
\hline & Provision of online spaces of conflict resolution \\
\hline
\end{tabular}

\section{NOTES}

1. I graciously acknowledge the contribution of Grace Monica Halim (Technical Officer, Labour Administration, ILO). In particular, I thank her for assistance with contacting ILO field Specialists covering the ILO Regional Offices of Africa, Middle East, Asia and the Pacific, Latin America and the Caribbean, who provided input for this chapter.

2. Replaced by the Department of Social Security by the time of publishing Margetts and Willcocks's (1992) study, and later, by the Department of Work and Pensions in 2001.

3. The 2015 ILO report found that similar systems were being replicated in other Gulf States, like the Sultanate of Oman, Qatar and Saudi Arabia.

4. See https://www.labour.gov.hk/eng/public/iprd/2016/chapter8.html (accessed 17 August 2021). 


\section{REFERENCES}

Aowsaf, A.S. (2018), 'Bangladesh labour inspectorate goes digital with LIMA', accessed 31 October 2018 at https://www.dhakatribune.com/business/2018/03/07/ bangladesh-labour-inspectorate-goes-digital-lima.

Arduini, D., F. Belotti, M. Denni, G. Giungato, and A. Zanfei (2010), 'Technology adoption and innovation in public services: the case of e-government in Italy', Information Economics and Policy, 22(3), 257-75.

Basu, S. (2004), 'E-government and developing countries: an overview', International Review of Law, Computers \& Technology, 18(1), 109-32.

Bekkers, V. and V. Homburg (2007), 'The myths of e-government: looking beyond the assumptions of a new and better government', The Information Society, 23(5), 373-82.

Blyton, P. and J. Jenkins (eds) (2007), Key concepts in work, London: SAGE.

Brown, D. (2005), 'Electronic government and public administration', International Review of Administrative Sciences, 71(2), 241-54.

Charih, M. and J. Robert (2004), 'Government on-line in the federal government of Canada: the organizational issues', International Review of Administrative Sciences, 70(2), 373-84.

Corbett, J. and S. Mellouli (2017), 'Winning the SDG battle in cities: how an integrated information ecosystem can contribute to the achievement of the 2030 sustainable development goals', Information Systems Journal, 27(4), 427-61.

Cordella, A. and F. Iannacci (2010), 'Information systems in the public sector: the e-government enactment framework', The Journal of Strategic Information Systems, 19(1), 52-66.

De Wispelaere, F., J. Pacolet, V. Rotaru, S. Naylor, D. Gillis, and E. Alogogianni (2017), 'Data mining for more efficient enforcement: a practitioner toolkit from the thematic workshop of the European Platform Undeclared Work', accessed 31 October 2018 at http://hdl.handle.net/1854/LU-8572421.

DWP (2012), Department for Work and Pensions Digital Strategy, accessed 13 February 2019 at https://assets.publishing.service.gov.uk/government/uploads/ system/uploads/attachment_data/file/193901/dwp-digital-strategy.pdf.

Ebisui, M., S. Cooney, and C. Fenwick (2016), Resolving individual labour disputes: a comparative overview, accessed 12 February 2019 at https:/www.ilo.org/wcmsp5/ groups/public/---dgreports/---dcomm/---publ/documents/publication/wcms_488469 .pdf.

Edgerly, S., E.K. Vraga, K.E. Dalrymple, T. Macafee, and T.K. Fung (2013), 'Directing the dialogue: the relationship between YouTube videos and the comments they spur', Journal of Information Technology \& Politics, 10(3), 276-92.

Fellows, J. (2010), 'The role of new technologies in the management and delivery of labour administration and inspection services: questionnaire analysis', working paper prepared for the ILO, 20 November.

Galazka, A.M. (2015), Report on the global survey into the use of information and communication technologies in national labour administration systems, Geneva: ILO, accessed 4 November 2018 at http:/www.ilo.org/wcmsp5/groups/public/--ed_dialogue/---ed_dialogue_msu/documents/publication/wcms_422057.pdf.

Galazka, A.M. (2017), Challenges to the use of information and communication technologies in labour administration, Geneva: ILO. 
Galazka, A.M., M.J. Beynon, and T. Edwards (2020), 'Index of information and communication technology use in labour administration: its need, its pertinence and its potential use', International Review of Administrative Sciences, 86(2), 240-60.

Gichoya, D. (2005), 'Factors affecting the successful implementation of ICT projects in government', The Electronic Journal of e-Government, 3(4), 175-84.

Hanson, V. (2018), Personal conversation with A. Galazka, 4 October 2018.

Hastings, T. (2016), Technical Report no. 2: ILO workshop on labour administration reforms and innovations: efficiency and outreach, accessed 17 August 2021 at https://www.ilo.org/global/about-the-ilo/how-the-ilo-works/departments-and -offices/governance/WCMS_506152/lang--en/index.htm.

Hastings, T. and J. Heyes. (2016), 'Comparative developments in labour administration', technical report, accessed 5 November 2018 at https://www.ilo.org/global/ about-the-ilo/how-the-ilo-works/departments-and-offices/governance/WCMS 506148/lang--en/index.htm.

Heron, R. and H. Van Noord (2004), National strategy on labour dispute prevention and settlement in Cambodia, Ministry of Labour and Vocational Training, Phnom Penh: ILO.

Heyes, J. and T. Hastings (2017), 'The practices of enforcement bodies in detecting and preventing bogus self-employment. European Platform Undeclared Work', accessed 13 February 2019 at https://ec.europa.eu/social/main.jsp?catId=1299\&intPageId= 4878\&langId $=$ en.

ILO (2015), Report of the Director-General to the International Labour Conference, 104th Session. Report I: The future of work centenary initiative, para 58, accessed 4 May 2017 at http://www.ilo.org/wcmsp5/groups/public/@ed_norm/@relconf/ documents/meetingdocument/wcms_369026.pdf.

ILO (2016), The Future of Work Initiative, accessed 31 October 2018 at http://www.ilo .org/global/topics/future-of-work/WCMS_448448/lang--en/index.htm.

ILO (2017), First cluster on Labour Laws Compliance System-Management Information System (LLCS-MIS) enhancements, accessed 31 October 2018 at http://www.ilo.org/ manila/eventsandmeetings/WCMS 584465/lang--en/index.htm.

ILO (2018a), Bangladesh Labour Inspectorate goes digital with LIMA, accessed 31 October 2018 at https://www.youtube.com/watch?v=D6dVuDx2ywA.

ILO (2018b), Bangladesh labour inspectorate goes digital with LIMA, accessed 31 October 2018 at http://www.ilo.org/dhaka/Informationresources/Publicinformation/ Pressreleases/WCMS_619879/lang--en/index.htm.

ILO (2018c), Building the capacity of the Philippines labour inspectorate, accessed 31 October 2018 at http://www.ilo.org/manila/projects/WCMS_379086/lang--en/ index.htm.

Irene, M. and G. Bunyasi (2017), 'Effects of information system and control environment on financial performance of state owned corporations in Kenya: a case study of the Ministry of Labour Social and Security Services, Journal of Finance and Accounting, 1 (1), 14-26.

Jho, W. (2005), 'Challenges for e-governance: protests from civil society on the protection of privacy in e-government in Korea', International Review of Administrative Sciences, 71(1), 151-66.

Kennedy, R. (2016), 'E-regulation and the rule of law: smart government, institutional information infrastructures and fundamental values', Information Polity, 21(1), 77-98.

Kim, L., J. Lee, and J. Lee, J. (1987), 'Korea's entry into the computer industry and its acquisition of technological capability', Technovation, 6(4), 277-93. 
Koeltz, D. (2013), 'Delivering public employment services: which model works best?', in Jason Heyes and Ludek Rychly (eds), Labour administration in uncertain times: policy, practice and institutions, Cheltenham, UK and Northampton, MA, USA: Edward Elgar and Geneva: ILO, pp. 163-93.

Lember, V., R. Kattel, and P. Tõnurist (2018), 'Technological capacity in the public sector: the case of Estonia', International Review of Administrative Sciences, 84(2), 214-30.

Liu, S.M. and Q. Yuan (2015), 'The evolution of information and communication technology in public administration', Public Administration and Development, 35(2), 140-51.

Margetts, H. and L. Willcocks (1992), 'Information technology as policy instrument in the UK Social Security System: delivering an operational strategy', International Review of Administrative Sciences, 58(3), 329-47.

Monavvarian, A. and M. Kasaei (2007), 'A KM model for public administration: the case of Labour Ministry', Vine, 37(3), 348-67.

Nam, T. (2012), 'Citizens' attitudes toward Open Government and Government 2.0', International Review of Administrative Sciences, 78(2), 346-68.

Nasi, G. and F. Frosini (2010), 'Vision and practice of e-government: an empirical study', Financial Accountability \& Management, 26(1), 85-101.

Ndou, V. (2004), 'E-government for developing countries: opportunities and challenges', The Electronic Journal of Information Systems in Developing Countries, 18(1), 1-24.

Páramo, P. and Maria Luz Vega (2017), 'New forms of work and labour inspection: the new compliance challenges', IUSLabor 2/107, accessed 10 November 2018 at https://www.upf.edu/documents/3885005/58976718/New+forms+work Paramo Vega.pdf/92b01c9f-89e8-04a7-ea4d-b44ecb8331dd.

Picazo-Vela, S., I. Gutiérrez-Martínez, and L.F. Luna-Reyes (2012), 'Understanding risks, benefits, and strategic alternatives of social media applications in the public sector', Government Information Quarterly, 29(4), 504-11.

Pina, V., L. Torres, and S. Royo (2010), 'Is e-government leading to more accountable and transparent local governments? An overall view', Financial Accountability \& Management, 26(1), 3-20.

Roux, L. (2015), 'Public service values and e-administration: an explosive mix? Illustration drawing on the case of the Family Allowance Funds (Caisses d'Allocations Familiales) in France', International Review of Administrative Sciences, 81(2), 227-44.

Shim, D.C. and T.H. Eom (2009), 'Anticorruption effects of information communication and technology (ICT) and social capital', International Review of Administrative Sciences, 75(1), 99-116.

Silcock, R. (2001), 'What is E-government', Parliamentary Affairs, 54(1), 88-101.

Sree Consultants (2019), Wages Protection System (WPS) in UAE, accessed 14 February 2019 at http://www.sreebusinessconsultants.com/wages-protection-system .html.

Stefanov, R. (2018), 'Risk assessment for more efficient inspections: setting the scene', presentation at the European Platform Undeclared Work Thematic Review Workshop, Madrid, 14-15 June.

Šiugždinienè, J., E. Gaulè, and R. Rauleckas (2019), 'In search of smart public governance: the case of Lithuania', International Review of Administrative Sciences, 85(3), $587-606$. 
Toregas, C. (2001), 'The politics of e-gov: the upcoming struggle for redefining civic engagement', National Civic Review, 90(3), 235-40.

Vega, M. (2013), 'Labour inspection systems: strengthening enforcement in times of crisis', in Jason Heyes and Ludek Ryckly (eds), Labour administration in uncertain times: policy, practice and institutions, Cheltenham, UK and Northampton, MA, USA: Edward Elgar and Geneva: ILO, pp. 222-44.

Vega, M. (2017), 'Is a critical re-evaluation of governance principles and institutions needed?', presentation at the Governance of Labour: Strategies for Sustainable Progress Global Workshop, Prague, 27 June.

Wark, S. and M. Thakur (2016), 'Promoting fundamental principles and rights at work - Phase III - in Sri Lanka', Sistemas, Familia y Sociedad, Consultores Asociados, accessed 27 October 2018 at https://www.dol.gov/ilab/projects/summaries/Sri \%20Lanka\%20Phase\%20III\%20Evaluation\%20Report\%2012-21-16\%20nonPII .pdf.

Welch, E.W., C.C. Hinnant, and M.J. Moon (2005), 'Linking citizen satisfaction with e-government and trust in government', Journal of Public Administration Research and Theory, 15(3), 371-91.

West, D. (2004), 'E-government and the transformation of service delivery and citizen attitudes', Public Administration Review, 64(1), 15-27.

Wu, J., S. Guo, H. Huang, W. Liu, and Y. Xiang (2018), 'Information and communications technologies for sustainable development goals: state-of-the-art, needs and perspectives', IEEE Communications Surveys \& Tutorials, 20(3), 2389-406. 